This report was prepared as an account of work sponsored by an agency of the United States Government. Neither the United States Governinent nor any agency thereof, nor any of their employees, makes any warranty, express or implied, or assumes any legal liability or responsibility for the accuracy, completeness. or usefulness of any information, apparatus, product, or process disclosed. or represents tal is use would not infringe privately owned rights. Reference herein to any specific commerciat product, process, or service by trade name, trademark, manufacturer, or otherwice does not necessarily constitute or inply its endorsement, recommendation, of favoring by the United States (iovernment or any agency thereof. The views and opinions of authors expressed herein do not necessarily state or reflect those of the United States Government or any agency thereof.

\title{
WELL, HYDROLOGY, AND GEOCHEMISTRY \\ PROBLEMS ENCOUNTEREN IN ATES SYSTEMS \\ AND THEIR SOLUTIONS
}
E. A. Jenne
0 . Andersson
A. Willemsen

August 1992

Presented at the Aquifer

Thermal Energy Storage

August 2-7, 1992

San Diego, California

Prepared for

the U.S. Department of Energy

under Contract DE-ACO6-76RLO 1830

Pacific Northwest Laboratory
Richland, Washington 


\title{
Title Sheet
}

\section{COVER INFORMATION FOR SAE TECHNICAL PAPERS}

\author{
PAPER TITLE \\ Well, Hydrology, and Geochemistry Problems \\ Encountered in ATES Systems and Their Solutions ${ }^{(1)}$
}

AUTHORS

1. E. A. Jenne

2. O. Andersson

3. A. Willemsen

\section{COMPANY}

1. Pacific Northwest Laboratory, P.O. Box 999, Richland, Washington 99352

2. VBB VIAK AB, Geijersgatan 8, S-21618 Malmo, Sweden

3. If 'Technology, Arnhem, The Netherlands 


\begin{abstract}
In aquifer thermal energy storage (ATES) systems, wells provide the interface between the energy storage and use. Efficient operational wells are, therefore, essential for the system to run at maximum (design) efficiency. Adequate test drilling to accurately predict aquifer properties is essential in the design phase; proper construction and development are crucial; and proper monitoring of performance is necessary to identify the early stages of clogging and to evaluate the adequacy of well rehabilitation. Problems related to hydrology, well, and aquifer properties include 1) loss of permeability resulting from gas exsolution, chemical precipitation, and dispersion and movement of fine-grained particles; 2) loss of recoverable heat caused by excessive regional ground-water gradient, hydrodynamic mixing of injected and native ground water, buoyancy flow (because of temperature-induced differences in water density), and heat conduction through the cap and base of the storage zone; 3) leakage up along the well casing; and 4) "fracturing" of a shallow upper aquiclude as a result of an injection pressure greater than the bydrostatic pressure on the aquiclude.

The predominant geochemical problems encountered are precipitation of carbonates in some areas and iron plus manganese oxides in others. These precipitation problems can be anticipated, and thus avoided, via geochemical calculations. The likelihood of iron carbonate $\left(\mathrm{FeCO}_{3}\right)$ precipitation is less certain because of the lack of adequate research. Corrosion is a frequent problem.

Most of the hydrochemically related clogging and corrosion problems that have been encountered in ATES systems can be predicted and avoided by appropriate design, construction, and operation of new ATES systems, assuming that a comprehensive and careful site investigation that includes appropriate bydrologic and geocbemical modeling is carried out in advance. Because of local variations in hydrology and water chemistry, each project must be carefully examined and the installation planned based on a knowledge of the kind of problems that could be encountered and site conditions. It is prudent to carefully consider the need for water treatment and to anticipate that there will be some increase in injection pressure and decrease of specific capacity over time. Therefore, the design should include 1) the capability to monitor the specific capacity, 2) an injection pressure control, 3) a permanent backflush system, and 4) a safety valve.
\end{abstract}

(1) The U.S. portion of this work was supported by the U.S. Department of Energy under Contract DEAC06-76RLO 1830. Pacific Northwest Laboratory is operated for the U.S. Department of Energy by Battelle Memorial Institute. 


\section{INTRODUCTION}

Aquifer thermal energy storage (ATES) systems make it possible to achieve large storage volumes, hence a large potential energy transfer, and obtain economy of scale, particularly if local ground-water gradients are small. A driving force for alternative energy forms is Europe's quest for energy self sufficiency (Rybach et al. 1988, Louwrier et al. 1988).

During the early studies of Iris (1979) and colleagues at the Ecole des Mines de Paris, the concept of seasonally recharging a solar/geothermal doublet was developed and commercialized for an urban area containing 200 housing units near Paris, France (Hadorn et al. 1990). Since then the majority of ATES systems involve the doublet concept. However, because of the loss in recoverable heat caused by buovancy flow experienced at Colombier, near Neuchatel, the second Swiss ATES site (known as SPEOS) utilized a novel radial drain design in separate but adjacent aquifers.

China clearly leads in utilization of chill storage having had "several years of experimentation" by 1965 (Yan and Woo 1981), with as many as 500 wells in Shanghi province alone (Lundin 1990). There are various other heat and/or chill storage sites not included in this review because they were not reported in our primary sources.

Many ATES systems have storage temperatures in the range of 12 to $40^{\circ} \mathrm{C}$, but there have been only six with temperatures of $>85^{\circ} \mathrm{C}$ (Horsholm, Mobile, Plaisir, SPEOS, St. Paul, and Utrecht; Lundin 1990, Molz et al. 1983, Willemsen 1992).

The objective of this paper is to review the technical design and implementation problems encountered to date in ATES systems worldwide, exarnine the extent to which these problems are unique to ATES as upposed to generic problems known to the applicable disciplines, and identify the solutions exploited to resolve these problems so that they can be avoided in future ATES systems.

The scope of this review includes those ATES systems that have been recorded in the Seasonal Thermal Energy Storage (STES) newsletter, the JIGAS'TICK' 88 and THERMASTOCK'91 conference proceedings, or are included within Internatioual Energy Agency (IEA) Annexes III, VI, and VII and for which enough information was found to make a meaningful entry into the Appendix table. Thus, the review is not allinclusive but does include the majority of all experimental and commercial ATES sites. Economic and environmental aspects of ATES systems are not considered in this paper. The information collected on problems and solutions has been summarized in the Appendix along with selected key information pertinent to the problem encountered. In the following text, ATES sites are referred to by their identification in the table (acronym, company, or city).

\section{WELL DESIGN AND CONSTRUCTION}

In ATES systems, wells provide the interface between the energy store and the remainder of the system; therefore, they are critical for the successful operation of the total system. Therefore, wells need to be carefully designed. drilled, and completed to prevent operational problems.

DESIGN CONSIDERATIONS - In a storage system, individual wells are generally used both for production and injection. Thus, they are operated under both hydraulic drawdown and pressure buildup conditions. For the latter case, this normally means a tight well-head construction to avoid gas escape and a pressure relief device to avoid excessive pressure. On the other hand, if the water level is low, a negative pressure can occur. In this case, airtight construction is necessary to avoid oxidation of Fe $\mathrm{F}^{\text {II }}$ by atmospheric oxygen; either a set of injection tubes of different diameters and/or a down-hole throttle may be necessary during the injection phase to prevent exsolution of dissolved gas and clogging of the aquifer with gas bubbles.

Because water almost always contains some particulates, most injection wells will clog with use. However, it has been shown that well performance after clogging from silt and sand-sized particulates can easily be restored by backflushing (Andersson 1988). However, specific capacity may be only partially restored if the clogging is due to clay-sized material or amorphic precipitates that may result from water clarification. If it is expected that frequent backflushing will be needed, it is advisable to design weils with a permanent backflushing system. 
CONSTRUCTION ASPECTS - Even drilling a well in an unconsolidated formation involves a risk of clogging, especiaily if a non-biodegradable mud is used as a drilling fluid. In this case, clogging is caused by fine-grained sediment entering the more permeable parts of the formation and lodging there (Glenn and Slusser 1970).

A loss of gravel pack permeability can occur while the screen and the gravel pack are being emplaced. If these components are not carefully installed, formation sediment may be admixed with the gravel pack, resulting in a permanent loss of permeability. Particle migration and bridging of pores during well operation, especially at high flow rates, may also result in clogging (Andersson 1988).

Short-circuit flow along the casing was a problem at the Mobile and Bunnik sites, allowing the mixing of the thermally altered water with native ground water (Molz et al. 1978). This occurs as a result of an inadequate seal above the gravel pack and upwards along the casing.

It is obvious that inadequate well design, improper drilling, or inadequate well construction can cause severe damage to the total ATES system. Therefore, adequate test drilling to accurately predict aquifer properties is essential in the design phase of the project. It is then up to the engineer and the well driller to carry out their work skillfully. To reduce potential drilling and well construction errors, some simple but important "guidelines" can be stated (Andersson 1990): 1) use biodegradable polymers instead of clay minerals (e.g., bentonite) in the drilling fluid, 2) before setting screen and gravel pack, circulate water until the hole is clean, 3) design screen slot size and gravel pack carefully to avoid sand production or clogged gravel pack, 4) spot weld down-hole pipe connections so that they cannot loosen and allow air entry, and 5) develop the well (e.g., by airlift) until the water is free of particulates and no sand is circulating.

\section{HYDROGEOLOGY}

FREE CONVECTION OR BUOYANCY FLOW - Buoyancy flow is the flow in the aquifer that is driven by the difference in density between hot and cold water (or between saline and tresh water). Buoyancy flow occurred at all sites where storage occurred at relatively high temperatures in aquifers with a higa permeability, i.e., Bunnik, Colombiar, Horsholm, SPEOS, Campuget, and Mobile. Buovancy flow can not be prevented for given hydrogeologic and storage conditions, such as thickness and permeability of the aquifer on the one hand, and temperatures and arnounts of water on the other hand. However, the amount and effect of buoyancy flow within a cycle can be reduced and the effect of buoyancy flow on the storage efficiency can be greatly minimized by implementing one or more of the following design measures:

- Inject warm water over the full beight of the aquifer and production of water only over some upper part of the aquifer as was done at Mobile, Horsholm, and Delft. The results from tests at Mobile and theoretical calculations on the subject by Buschek et al. (1983) show that this can significantly increase the thermal efficiency of the store.

- Drill horizontal instead of vertical wells as was done at SPEOS. When there are two levels of wells and the "warm" wells are above the "cold" wells, there will be a lavered store, as with short-term storage in tanks. In such a situation, the density difference will cause a stable situation when the lighter water is above the heavier, colder water. At SPEOS, it was subsequently found that there was a lowpermeability layer between the hot and the cold wells and that heat loss to the surface could be lowered significantly by switching the cold wells and warm wells.

- Prevent vertical flow through the (vertical) wells when pumping is stopped. At Bunnik, it was found that vertical flow through wells occurred and contributed significantly to the buovancy flow. Vertical flow was subsequently prevented by placing a packer in the warm well, which was manually closed when the store was not used. In practice it was found, however, that the packer leaked a lot of the nitrogen gas used to close the packer. This gas caused high pressures in the top layer of aquifer adjacent to the warm well.

BREACHING OF CONFINING LAYER (AOUICLUDE) - When the injection pressure becomes higher than the minimum pressure required to lift the confining laver, the confining laver will breach and the water will flow to the surface. This phenomena is known from artificial recharge (Olsthoorn 1982) and from injection carried out to minimize subsidence caused by a lowering of the ground-water table (Rijkswaterstaat 
1986). In general, the rule can be used that the injection pressure in meters of water head above the surface level should not be langer than 0.2 times the depth of the top of the screen below land surface. For the final design of an injection well, an accurate calculation of the allowed injection pressure should be made, taking into account the weight of the total column of rock and water above the top of the screen or above the top of the aquifer (whatever is the most critical point) and the angle under which the matrix is likely to start to move. Breaching of the confining layer occurred at Horsholm and may have occurred at Mobile. At Horsholm, a pressure transducer that should have shut down the system before too high an injection pressure was reached did not function properly. This is not an isolated occurance, as pressure transducers at St. Paul also failed. ${ }^{1}$ At Mobile, it was speculated that the failure may have been caused by piping along a improperly sealed well casing rather than breaching the aquiclude (Molz et al. 1978).

In general, breaching of the confining layer can be prevented by an adequate design of the storage system. Account should be taken of the necessary injection pressure during maximum flow and of possible clogging. Also, safety measures should be taken such that the system shuts off above a certain injection pressure. One should therefore not rely on a single pressure transducer.

THERMA.L BREAKTHROUGH - The injection and production wells should be at an optimum distance from each other that should allow for the maximum required amount of energy to be stored. Whether any influence of one side on the temperatures at the other side is desired depends on the injection temperatures with respect to the natural ground-water temperatures. If the injection temperatures at the "warm" and "cold" sides of the store are such that the natural ground-water temperature is between those temperatures, then thermal breakthrough is undesirable. Undesirable thermal breakthrough occurred, for example, at Kristianstad. If, on the other hand, "warm" and "cold" sides have injection temperatures that are both below or above the natural ground-water temperature, then some thermal breakthrough is wanted. Kowalczyk and Havinga (1991) performed calculations on the thermal efficiency of a store as a function of well distance. They showed that the optimum well distance depends on the type (heat, cold, or combined) and the temperatures of the store. In case the injection temperatures are on both sides of the natural ground-water temperature, the radius of influence of cold and warm well should not reach each other (well distance larger than 3 times $R t h$ ). In the other case the wells should be in each other's range of influence (well distance approximately 1 to $2 \mathrm{Rth}$ ). The potential for thermal breakthrough depends of course also on the regional flow, the direction of this flow with respect to the locations of the wells and on the existence of preferential flow paths.

PREFERENTIAL FLOW PATHS - Aquifers normally exhibit higher permeability in some layers than in others, resulting in a greater volume of water being injected into the higher permeability laver(s). The effect of variable permeability layers is to increase the surface area of the store and, therefore, the thermal losses. The flow of thermally altered water to a greater distance in some lavers than other, cannot be prevented, but the following countermeasures can be taken to prevent excessive losses caused by preferential flow paths.

- If feasible, use (screen) only the part of the aquifer exhibiting similar permeability values.

- Contrary to the standard practice with water production wells of using the maximum slot size and gravel pack grain size that is allowed by the grain size in the aquifer, for ATES wells an (small) increase in resistance to flow across the screen and gravel pack may be beneficial by causing the injected water to be distributed more uniformly over the various aquifer lavers. This approach will, of course, reduce the specific capacity.

REGIONAL FLOW - Where regional gradients in pressure head in the aquifer are relatively large and the permeability of the aquifer is high, there will be a significant regional flow that will cause part of the stored energy to be lost. Significant losses from regional flow occurred at Bunnik, SPEOS, and Tuscaloosa (Schaetzle and Brett 1989). The losses caused by regional now can be minimized by altering the upstream head or effective permeability by developing

- An active gradient control or "bypass" for the regional flow wherein the upstream head is reduced by pumping from one or more wells upstream of the store to one or more downstream wells (transfer to

\footnotetext{
${ }^{1}$ M. Hover, Oral Communication.
} 
surface water as is now done at Tuscaloosa). Willemsen and Groeneveld (1989) showed with computer calculations that such a bypass can effectively reduce the effect of the regional flow on the thermal efficiency of the store to zero.

- Passive gradient control wherein the impact of regional flow is minimized by judicious control of pumping schedules can be effective if the regional flow is not too great (Schaetzle and Brett 1989).

- Low-permeability screen around the store, as proposed by Hadorn et al. (1990) whose calculations have shown that such a screen can significantly reduce the effect of the regional flow on the thermal efficiency.

Both of these methods to decrease the extent of the regional flow through the aquifer store require significant investments, and care must be taken to ensure that they are cost effective. A low-permeability screen is only feasible in shallow aquifers. Other methods that may be used to reduce the loss in the efficiency of the store without actually reducing the regional flow itself are to

- Inject into the store upgradient of the recovery well. This requires that the quality of the energy in the upstream part is higher, the wells are in line with the regional flow, and that the warm and cold sides are both higher or lower than the natural ground-water temperature. Otherwise, steps must be taken to minimize thermal breakthrough, which means that the wells have to be placed orthogonal with respect to the regional flow.

- Inject more water in the upstream than downstream well and/or produce more from the downstream than in the upstream well. This implies that the wells on each side have to be placed in the direction of flow.

However, application of these methods may also involve significant cost.

\section{GEOCHEMICAL SCALING AND CLOGGING}

As is evident from the Appendix table, scaling of heat exchangers and clogging of wells, gravel pack, adjacent aquifer caused by chemical precipitates has been frequently encountered in existing ATES systems, especially the precipitation of carbonates in the systems operating above $85^{\circ} \mathrm{C}$ and $\mathrm{Fe}$ and $\mathrm{Mn}$ oxides in low temperature $\left(<40^{\circ} \mathrm{C}\right)$ systems.

CARBONATES - Scaling (i.e., precipitation within the above-ground portion of an ATES system) and precipitate-induced aquifer clogging (i.e., reduced aquifer permeability caused by precipitation within the aquifer) results from carbonate and $\mathrm{Fe}$ plus $\mathrm{Mn}$ oxide precipitation. Problems with carbonates has occurred at St. Paul, SPEOS, Horsholm, and Plaisir (Appendix). Extensive clogging occurred at St. Paul because the engineers and geologists involved were unaware of the inverse solubility of carbonate minerals with temperature. Subsequently, the quantity of carbonate available for precipitation was underestimated; hence, precipitation cylinders clogged within a day or so because of the extensive precipitation that occurred. A Naion exchange system was subsequently installed that has been essentially trouble-free. At SPEOS, carbonate precipitation was prevented by adding acid for some years; but, the acid addition was terminated because of increasing $\mathrm{Cl}$ concentration and hardness levels of the water. Since then, there has been continuing experimentation with a variety of physical approaches ("non-sticking heat exchanger coatings," recirculation of plastic balls), alkali addition to raise the $\mathrm{pH}$, and fluidized bed heat exchangers. However, as these treatments resulted in fine-grained carbonate precipitates that have frequently clogged the well/aquifer interface. At Horsholm, as at SPEOS, acid addition was used to prevent carbonate scaling. Aquifer clogging at Plaisir occurred when the treatment control system failed. In the later stage of this project, a cation exchanger was installed and no further carbonate clogging was encountered.

Thus, Na-exchange resins provide a trouble-free method of avoiding carbonate scaling and clogging, as long as care is taken to ensure that clay swelling and/or dispersion does not occur and the disposal of the acid or salt used to recharge the resin is not a problem. The likelihood of clay swelling/dispersion can be estimated from the sodium adsorption ratio and used in conjunction with the salinity of the water. An environmental consequence of the cation exchange method is that sizable amounts of either salt or acid, used in recharging the exchange resin, must be discharged to surface or ground water. 
Although not yet implemented in other than an experimental mode, a fluidized bed heat exchanger with an in-line activated carbon column to remove dissolved organic carbon has recently been successfully tested. ${ }^{2}$

IRON AND MANGANESE HYDROXIDE PRECIPITATION - The precipitation of Fe and $\mathrm{Mn}$ oxides is caused by a change in water chemistry. Precipitation of $\mathrm{Fe}^{\mathrm{III}}$ axides can be induced by increasing either the redox potential $(\mathrm{Eh})$ or the $\mathrm{pH}$. As illustrated in the $\mathrm{Fe}$ stability field diagram shown in Figure 1 , if either the $\mathrm{Eh}$ or $\mathrm{pH}$ of a slightly reduced water (point $\mathrm{A}$ in the diagram) is increased, precipitation of $\mathrm{Fe}$ axides is likely. Not shown on this figure is the effect of Fe concentration; as Fe concentration increases, its oxide will precipitate at progressively lower $\mathrm{Eh}$ and $\mathrm{pH}$ values. In practice, there are at least three prosesses involved to create the Eh and $\mathrm{pH}$ changes. Those are (Andersson 1990) 1) oxygen is added from some source and the Eh value is increased (displacement from $A$ to $B$ in Figure 1);2) waters differing in their Eh status are mixed upon entering the well causing either an increase or decrease in $\mathrm{Eh}$ and possibly $\mathrm{pH}$ ( $\mathrm{A}$ to $\mathrm{B}$ or $\mathrm{B}$ to $\mathrm{A}$ ); or 3) carbon dioxide escapes from the water, increasing the $\mathrm{pH}$-value (A to $\mathrm{C})$. The latter process is also believed to be one of the main factors causing the precipitation of carbonates in a well with little or no scaling in the heat exchanger. Where there are significant Fe concentrations, Fe carbonate rather than Ca carbonate may precipitate. Although definitive information is not yet available, the precipitation of Fe carbonate is suspected at several locations in Sweden (e.g., Lomma). The Fe carbonate precipitate in these cases is not readily solubilized by acid treatment of the well.

Shallow, unconfined aquifers generally bave levels of $\mathrm{Fe}$ and $\mathrm{Mn}$ that are likely to yield axyhydroxide precipitates if air is allowed to enter the ATES system. Some Fe axide, along with pyrite, was found on the heat exchanger at Horsholm, presumably the result of partial oxidation of dissolved sulfides caused by air leaking into the system. An air leak in the ATES system at Bunnik caused Fe and $\mathrm{Mn}$ scaling of the well screen. Iron oxide precipitation was presumed to be the cause of clogging at Klippan.

However, none of the processes causing Fe oxide precipitation need occur during injection if the system is airtight, and the aquifer is selected or the hydrology is controlled to eliminate the mixing of dissimilar waters near the well. For these reasons, the likelihood of Fe oxide clogging during injection is low in a properly designed system. If for any reason an airtight system is not feasible, any one of a number of iron removal methods may be used (Vail et al. 1992). The principal processes leading to a greater likelihood of clogging in production and injection wells with water containing elevated levels of Fe are illustrated in Figure 2.

CLOGGING BY MICROBIAL GROWTH - Clogging by biofilm or microbial slime is a well-known phenomena in the water-well industry (Driscoll 1986). The most frequent biologically caused well clogging is that associated with iron bacteria, especially the ones belonging to the Gallionella family. However, in a highly reduced environment, clogging can also be associated with sulphur bacteria. In ATES applications, clogging by iron bacteria slime will is a potential risk mainly in low-temperature systems (less than $25^{\circ} \mathrm{C}$ ) and in waters with an iron content of at least $1 \mathrm{mg} / \mathrm{L}$. Other conditions that favor major bacterial growth are Eh values between 200 and $400 \mathrm{mV}$ and $\mathrm{pH}$ values between 5.5-7.5.

GAS CLOGGING - Gas clogging may occur as a result of the exsolution of gases present in excess of the amount that would be present at equilibrium with air at atmospheric pressure. This occurred at Delft because of the methane overpressure in the source/storage aquifer, and presumably at Scarborough (see Appendix), but did not occur at Utrecht, because a total pressure sufficient to maintain the dissolved gas in solution was maintained at the latter site.

CLAY DISPERSION - Swelling and dispersion of clays contained within the aquifer sediment occurs when the Na saturation exceeds an amount determined by the ionic strength (i.e., conductivity) of the water (Willemsen 1992). Clay swelling and dispersion are unlikely to pose a problem in consolidated or silicacemented aquifers even when the water is passed through a Na ion exchanger repetitively, as at St. Paul. However, it is the suspected cause of the last clogging problem encountered at Plaisir. ${ }^{3}$ Clay swelling

2 A. Willemsen, Unpublished Data.

3 A. Vinsot, Personal Communication. 
and/or dispersion has been avoided at Utrecht, by treating the minimum fraction of the water necessary to prevent carbonate scaling; no scaling is observed at a calcite saturation indices of 0.6 to 0.7 (Willemsen 1992). A large amount of sediment was recovered at Mobile (Molz et al. 1983). The amount of suspended sediment may have been increased by the use of a foreign water (i.e., local surface water) into the aquifer and/or the inadequacy of the gravel pack.

\section{CORROSION}

Both chemical and electrochemical corrosion occur in ATES systems. Chemical corrosion is induced by constituents such as $\mathrm{CO}_{2}, \mathrm{O}_{2}, \mathrm{H}_{2} \mathrm{~S}$, dissolved sulfide, chloride, and sulphate. Sites that have used $\mathrm{HCl}$ to remove or prevent carbonate precipitation, e.g., SPEOS and Horsholm, bave experienced significant corrosion. Corrosion was also experienced when a pipe connection was not sufficiently tight and ailowed a small amount of air to diffuse through the threaded joint and react with reduced ground water (Andersson 1992). Electrochemical corrosion appears to be more frequent than chemical corrosion. Electrochemical corrosion is caused mainly by joining metals with different electrochemical potentials but electrochemical corrosion also occurs on monometallic components that have been stressed, e.g., welded joints, cut surfaces or damaged coatings. Further, it seems that electrochemical corrosion causes loss of material only on parts of well screens and casings. Usually it occurs in water that is slightly acidic and with total dissolved solids greater than about $1000 \mathrm{mg} / \mathrm{L}$ (Driscoll 1986).

Protection against corrosion is in most cases dependent upon the choice of materials for each specific system. For instance, different steel alloys may cope with expected corrosion, as well as plastic materials, ceramics, or corrosion-resistant coatings. A world-wide method for galvanic corrosion protection of wells is to use a cathodic protection system, normally accomplished by connecting a sacrificial anode to the well casing (Driscoll 1986).

\section{CONCLUDING DISCUSSION}

Most of the hydrochemically related clogging and corrosion problems that have been encountered in ATES systems can be predicted and avoided by appropriate design, construction, and operation of by performing a comprehensive and careful pre-investigation. Because of local variations in hydrology and water chemistry, each project must be carefully examined and the installation planned on the basis of a knowledge of the kind of discussed in this paper that could be encountered and specific site conditions.

Virtually all common hydrologic and geochemical problems have been encountered at one or another of the ATES sites (e.g., buovancy flow, breaching of confining layer, gravel pack failure, particle clogging, air clogging, methane clogging, precipitation $\mathrm{Fe}$ and $\mathrm{Mn}$ oxides), in addition to carbonate precipitation which is somewhat unique to ATES and geothermal systems. It is prudent to anticipate some build-up in injection pressure and decrease of specific capacity over time and therefore, to include in the design 1) the capability to monitor the specific capacity, 2) an injection pressure control with more than one transducer, 3) a permanent backflush system, and 4) a safety valve.

Clogging is the most frequent problem encountered in ATES systems. Rapid filtration (e.g., sand, fiber filters) and frequent backflushing is effective against particle clogging. Backflushing may need to be done as frequently as twice daily, as in the chill storage wells in Shanghai province during charging (Lundin 1990). Bacierial biofilms or slime are rarely a problem unless the water being stored is a surface water or has been enriched in nutrients and/or energy substrates. It is presumably for this reason that the water ased to cool the cotton mills in Chanzhou is not only filtered three times but is chlorinated twice (Shen 1988, Yong-Fu et al. 1991). Where Fe precipitation is a potential problem, confined aquifers are preferred and care should be taken that $\mathrm{CO}_{2}$ is not allowed to form a separate gas phase nor to escape. It is also desirable to limit the drawdown to the minimum extent possible.

Iron oxide and $\mathrm{Ca}$ carbonate solubility, as well as clay swelling and dispersion calculations have been found reliable in predicting when these problems will not occur. However, not enough experience has vet been gained to allow the prediction of Fe carbonate precipitation. Research on this problems, as well as on the effects of kinetic inhibitors (e.g., $\mathrm{DOC}, \mathrm{PO}_{4}, \mathrm{Mg}$ ) on $\mathrm{Ca}$ carbonate precipitation and complexation with 
dissolved organic carbon on the apparent oversaturation of Fe oxides is underway within Annex VI of the IEA.

Steps to detect and avoid corrosion include 1) not allowing contact between metals or alloys with different electrochemical potentials, 2) not allowing oxygen to enter the system at any point, and 3) avoiding the use of acid to prevent scaling and clogging, and 4) installing a corrosion detector.

\section{CONCLUSIONS}

- There is an acute need for greater use of multi-discipline experience in the design and implementation of ATES because most technical problems encountered to date could have been avoided if they had been anticipated in the design, construction, and implementation stage and the appropriate steps taken to prevent their occurrence.

- From a hydrogeological point of view, confined aquifers are strongly preferred over unconfined aqrifers, because the potential for mixing of reduced and axidized waters is much reduced.

- Minimize buoyancy flow losses by injecting thermally altered water over the full height of the aquifer but produce only from the upper part of the aquifer, or drilling horizontal instead of vertical wells, and install a means of preventing flow from hot to cold sides of the store during periods when pumps are not operating.

- Use best available hydrologic modeling to optimize distance between warm and cold wells.

- Losses from excessive regional flow can be minimized by lowering the upstream head by pumping or by injection an appropriate distance up gradient of the recovery well.

- Multiple pressure transducers should be included in the design to shut down the system before excessive pressures can cause a breaching of the confining laver.

- Closed systems are generally essential io avoid loss of carbon dioxide and entrance of air.

- Where the aquifer is over-pressured with carbon dioxide and/or methane, a sufficient overpressure must be maintained to avoid the exsolution of these gasses to form discrete gas phase which can clog the aquifer.

- The drawdown of an aquifer containing significant Fe concentrations during production should be limited to the extent possible, to avoid local degassing and a possible $\mathrm{pH}$ rise, by using highly permeable aquifers or additional wells. 


\section{REFERENCES}

AJ91 Abyharnmar, T., S. Johansson, S. Bergluug, and A. Eriksson. 1991. The Aquifer Energy Sustem at SAS Main Office in Solna - Evaluation. R14:1991, Swedistı Council for Building Research, Stockholm, Sweden (in Swedish).

Andersson, O. 1988. "Injection Well Designing Requires Special Concerns." In Geohydrology in Practice Symposium. VIAK AB, Stockholm (in Swedish).

Andersson, O. 1990. "Scaling and Corrosion in Subsurface Thermal Energy Storage Systems." In J.C. Hooghart and C.W.S. Posthumus (eds), Hydrochemistry and Energy Storage in Aquifers. TNO Technical Meeting 48, Ede, The Netherlands.

An92a Andersson, O. 1992a. "Evaluation of the Well Development at Lomma ATES Plant." Swedish Council for Building Research. Stockholm, Sweden.

An92b Andersson, O. 1992b. Operational Monitoring of the Sparven ATES Plant. Consultant Commission Report on Behalf of Telaris, Malmö. VBB VIAk AB, Malmö, Sweden.

BS85 Bruggen, R.J.A. van der and A.L. Snijders. 1985. "Heating of an Office Building Using Solar Energy in Combination with a Heat Pump and Seasonal Heat Storage." In Proceedings ENERSTOCK'85. Public Works Canada, Ottawa, Canada.

BD83 Buschek, T.A., C. Doughty, and C.F. Tsang. 1983. "Prediction and Analysis of a Field Experiment on a Multilavered Aquifer Thermal System with Strong Buoyancy Flow." Water Resources Res. 19:1307-1315.

Da91 Dalton, M. 1991. Questionnaire for Review of Cold Storage Projects within IEA-Annex 7. Hickling Corp., Ottawa, Canada, February 1991.

Driscoll, F. G. 1986. Groundwater and Wells. Second Edition. Johnson Division, St. Paul, Minnesota.

EH 83 Emmelin, A., H. Hydren, and L. Lemmeke. 1983. Storage of Surface Water in a Sand Aquifer for the District Heating System in Klippan. R146:1983, Swedish Council for Building Research, Stockholm, Sweden (in Swedish).

Glenn, E. and M. Slusser. 1970. "Factors Affecting Well Productivity." Series of Articles in Well Completions, Petro. Trans. Reprint, Series No. 5.

GR89 Gustafson, G., P-A. Ryttar, and K. Norback. 1989. Storage of Heat bv induced Infiltration of Surface Water. R30:1989, Swedish Council for Building Research, Stockholm, Sweden (in Swedish).

HM91 Haak, A.M. and B. Minnema. 1991. "National Testing Facility for Cold and Heat Storage in Aquifers, The Netherlands. First Experience: Well Injectivity Potential." In Proceedings THERMASTOCK'91. NOVEM, Utrecht, The Netherlands.

HC90 Hadorn, J-C., D. Chuard, P. Jabovedoff, and P. Chuard. 1990. Guide to Seasonal Heat Storage. SLA, Swiss Federal Energy Office and Swiss Association of Engineers and Architects, Zurich, Switzerland. (Originally published in Switzerland in 1987, Translated into English in 1990 by J. Boake for Public Works Canada.) 
HE91 Hoyer, M.C., S.J. Eisenreict, N.L. Hoim, T.R. Holm, R. Kanivetsky, M.A. Jirsa, H.C. Lee, H.L. Laure, R.T. Miller, J.L. Norton, and H. Runke. 1991. The University of Minnesota Aquifer Thermal Energy Storage (ATES) Field Test Facility - System Description. Aquifer Characterization, and Results of Short-Term Test Cycles. PNL-7220, Pacific Northwest Laboratory, Richland, Washington

IQ91 Ibsen, L., B. Qvale, and C. Boesen. 1991. "Windup of the Danish Aquifer Thermal Energy Storage Plant. Answers Gained and Questions Remaining," In Proceedings THERMASTOCK'91. NOVEM, Utrecht, The Netherlands.

Iris, P. 1979. "Héliogéothermie à faible profondeur avec pompe à chaleur associée." Expe'rimentation de stockage de chaleur interaisonnier en nappe phre'atique a' Campuget (Gard) Rapport Plan Construction. Pairs. (Cited in Hadorn 1990).

Ir80 Iris, P. 1980. "Experimental Study of Heat Storage in Aquifer," in C. den Ouden (ed) Thermal Energy Storage of Solar Energy. Marinus Nijhoff, The Hague, The Netherlands.

IV88 Iris, P. and P. Viennot. 1988. "An Example of Heat Pumps on Aquifer for Collective Dwellings: Comments After 5 Years of Operation." In Proceedings JIGASTQCK'88. AFME, Paris, France.

IV85 Iris, P, P. Viennot, J.Y. Ausseur, and J.P. Sauty. 1985. "Heat Storage and Heat Pumps on Aquifer Two Case Studies," In Proceedings ENERSTOCK'95. Public Works Canada, Ottawa, Canada.

Jenne, E. A. 1968. "Controls on Mn, Fe, Co, Ni, Cu, and $\mathrm{Zn}$ Concentrations in Soils and Water the Significant Role of Hydrous Mn and Fe Oxides." Advances in Chemistry 73:337-387. American Chemical Society.

KL91 Kooiman, L. and L.J.M. van Loon. 1991. "Demonstration Project: Perscombinatie NV Amsterdam: Cold Storage in Aquifer." In Proceedings THERMASTOCK'91. NOVEM, Utrecht, The Netherlands.

KH91 Kowalczyk, W. and J. Havinga. 1991. "A Case Study on the Influence of the Distance Between Wells on a Doublet Well Aquifer Thermal Performance." In Proceedings THERMASTOCK'91 NOVEM, Utrecht, The Netherlands.

Kr91 Kronqvist, L. 1991. Aquifer Energy Storage - Evaluation of Kristianstad. R40:1991, Swedish Council for Building Research, Stockholm, Sweden (in Swedish).

La92 Landberg, J. 1992. Evaluation of the Combined Warm and Cold Storage at The Triangle, Malmō. Swedish Council for Building Research, Stockholm, Sweden.

LP91 Loon, LJ.M. van, and A. Paul. 1991. "Aquifer Thermal Energy Storage at the State 'Jniversity of Utrecht, The Netherlands." In Proceedings THERMASTOCK'91. NOVEM, Utrecht, The Netherlands.

Louwrier, K., E. Staroste, and J.D. Garnish. 1988. "Geothermal Research in the European Community." In Proceedings JIGASTOCK'88 1:37-43. AFME, Paris, France.

Lu90 Lundin, S-E. 1990. "Heat Storage in Aquifers." In Proceedings JIGASTOCK'88 3:971-975. AFME, Paris, France. 
Mi92 Mirza, C. 1992. Aquifer Thermal Energy Storage Systern Canada Center Building Scarborough. 1992 Well Efficiency Testing. File S•92•331 (dated 1992•04•13). Strata Engineering Corp., Don Mills, Ontario, Canada.

MM83 Molz, FJ., J.G. Melville, O. Guven, and A.D. Parr. 1983. Design. Performance and Analysis of an Aquifer Thermal Energy Storage Experiment Using the Doublet Well Configuration. PNL-4849, Pacific Northwest Laboratory, Richland, Washington.

MLS5 Molz, FJ., J.C. Warman, and T.E. Jon zs. 1978. "Aquifer Storage of Heated Water: Part I - A Field Experiment." Ground Water 16:234-241.

Ois2 Olsthoorn, T.N. 1982. Clogging of Recharge Wells. KrWA, Kijswijk, The Netherlands. (in Dutch; short English version available)

PD91 Pfiffer, M. M. Durin, J. Despois and B. Fritz. 1991. "The Heat Storage Project at Plaisir-ThivervalGrignon (France)." In Proceedings THERMASTOCK'91. NOVEM, Utrecht, The Netherlands.

Ry86 Rijkswaterstaat. 1986. Groundwater Infiltration in Bored Wells. Rijdswaterstaat, The Hague, The Netherlands.

Rybach, L., A. Feur, and D. Roux. 1988. "The Swiss System of Government Risk Coverage for Geothermal Drilling." In Proceedings JIGASTOCK'88 1: 19-21. AFME, Paris, France.

SG91 Saugy, B., O. Graf, S. Ward, S. Germano, E. Recordon, R. Crottaz, F. Favrat, J.M. Colomb, P.A. Riedo, and J.P. Baraben. 1991. "Project SPEOS-Recent Developments." In Proceedings THERMASTOCK'91 1.17, 6 p. NOVEM, Utrecht, The Netherlands.

SG82 Sauty, J.P., A.C. Gringarten, H. Fabris, D. Thiery, A. Menjoz and P.A. Landel. 1982. "Sensible Heat Storage in Aquifers - Part II: Field Experiments and Comparison with Theoretical Results." Water Resour. Res. 18:253-265.

SB89 Schaetzle, W.J. and C.E. Brett. 1989. The Aquifer Chill Storage Project at the University of Alabama, Tuscaloosa: Progress Report for 1985 and 1986. PNL-6797, Pacific Northwest Laboratory, Richland, Washington.

Sh88 Shen, G.J. 1988. "Research on Energy Storage In the Underground Water and its Quality in Chang7hou City." In Proceedings JIGASTOCK'88 1:337-341. AFME, Paris, France.

ST85 Shen, G.J., Y. Tang, and B.Q. Pang. 1985. "Research on Energy Storage in the Underground Water and its Quality in Changzhou City." In Proceedings IIIrd International Conference on Energy Storage for Building and Cooling. Public Works Canada, Ottawa, Canada.

SZ88 Shen, GJ. and Y. Zheng. 1988. "The Characters of Land Subsidence and Mechanism Analysis of Changzhou City." In Proceedings JIGASTOCK'88 2:843-846. AFME, Paris, France.

SS82 Supkow, J. and J.A. Shultz. 1982. "Analysis of Reinjection Problems at the Stony Brook ATES Field Test Site." STES Newsletter IV:5.

Vail, L.W., E.A. Jenne, and L.E. Eary. 1992. "H2OTREAT: A Software Aid for Evaluating Water Treatment Requirements for Aquifer Thermal Energy Storage. (this proceedings). 
VC91 Vinsol, A. and A. Coudrain-Ribstein. 1991. "Geochemical Impact of A Seasonal Heat Storage in an Aquifer in Trappes, France: Field Measurements and Mathematical Modelling." In Proceedings THERMASTOCK'91. NOVEM, Utrecht, The Netherlands.

Wa84 Walton, M. 1984. "Status of St. Paul Minnesota Energy Storage Project." In Summarv of

Presentations Fifth Expert Meeting, IEA Energy Conservation Through Storage Annex III, p. 115135. Lausanne, Suitzerland.

Willemsen, A. 1992. "PHREEQM-2D: A Computer Modei to Calculate Geochemical Reactions During Transport of Groundwater - Model Description and Application to the Utrecht University ATES." (this proceedings).

WG89 Willemsen, A. and G.J. Groeneveld. 1989. "Environmental Impacts of Aquifer Thermal Energy Storage (ATES): Modeling of the Transport of Energy and Contaminants from the Store." In G. Jousma et al. (ed), Groundwater Contamination: Use of Models in Decision Making. Kluwer Academic Publishers, Dordrecht, The Netherlands.

Yan, Q.-S. and T.-F. Woo. 1981 "The Development and Application of Aquifer Storage in China." STES Newsletter III:4-5.

YQ91 Yong-Fu, S., L. Qin-fen, and W. Ji-hong. 1991. "The Experiment of Storing Cold and Warm Water in Aquifer in Shanghai, P. R. China and Its Effect." In Proceedings THERMASTOCK'91, 1.1, 7 pp. NOVEM, Utrecht, The Netherlands. 


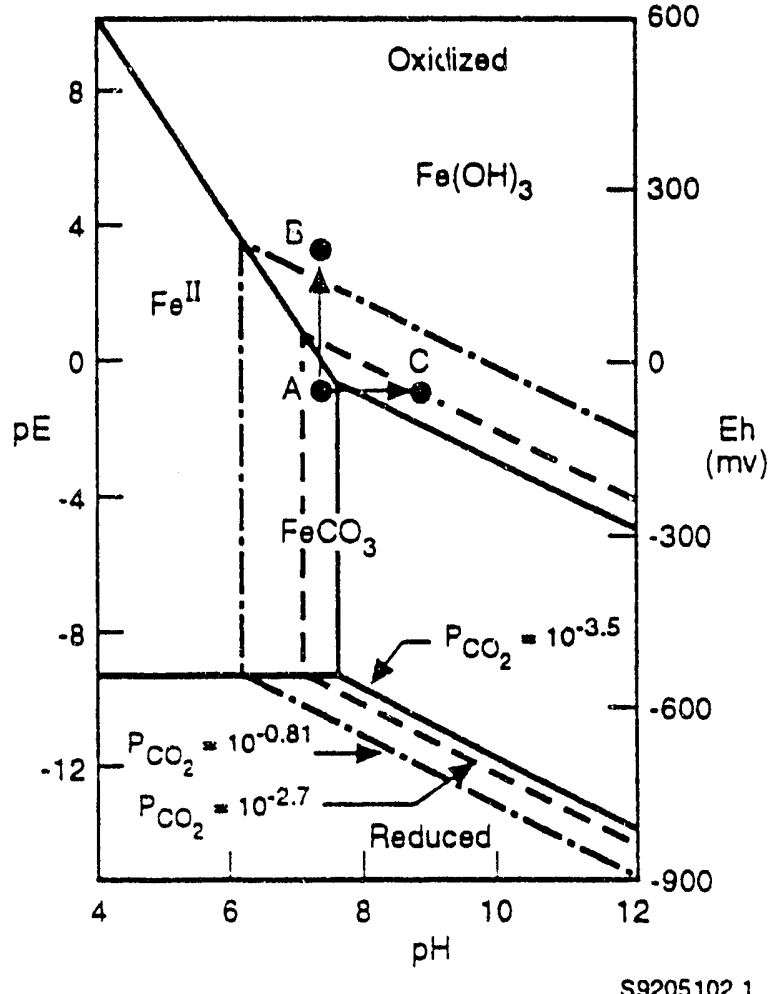

Figure 1. A portion of the Eh (or $\mathrm{pE}$ ) versus $\mathrm{pH}$ stability field for iron illustrating the likely precipitation of ferric hydroxide and/or ferrous carbonate (siderite) as result of a change in Eh or $\mathrm{pH}\left(\mathrm{a}_{\mathrm{Fe}}=10^{-4} \mathrm{M}\right.$, temperature $=25^{\circ} \mathrm{C}$; after Jenne 1968). 

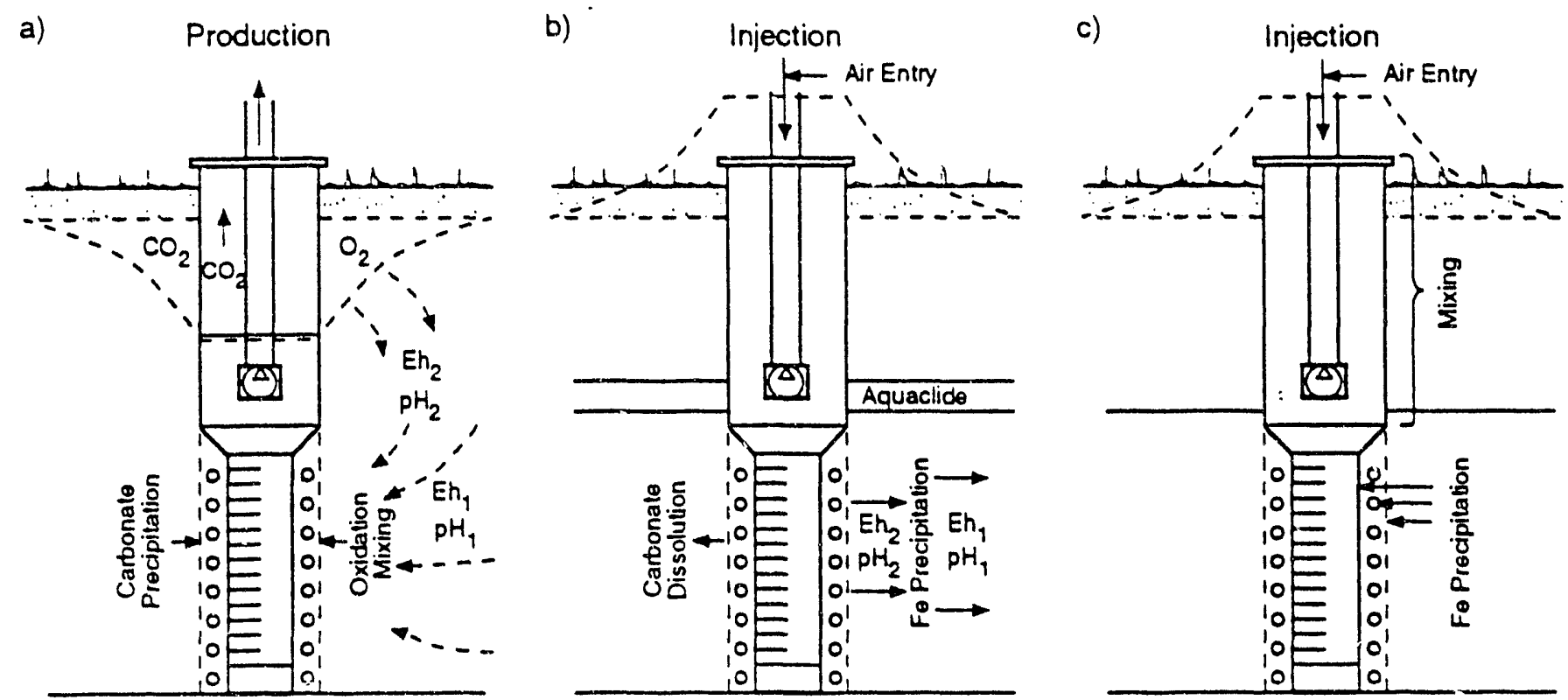

S9205102.2

Figure 2. Illustration of hydrologic and geochemical processes that facilitate the precipitation or dissolution of carbonates and/or $\mathrm{Fe}$ and $\mathrm{Mn}$ oxides in or close to (a) production well in an unconfined aquifer (carbonate and $\mathrm{Fe} / \mathrm{Mn}$ oxide precipitation) as contrasted to (b) a well where oxygen-containing water that is undersaturated with respect of Fe oxides (e.g., surface water or treated ground water) and carbonate is injected into a confined aquifer that contains elevated levels of dissolved $\mathrm{Fe}$ resulting in potential carbonate dissolution as well as Fe.Mn oxide precipitation remote form the well itself, and (c) injection of Fe-rich water where air is allowed to enter the system resulting in Fe oxide precipitation on the well screen, gravel pack, and adjacent aquifer. 


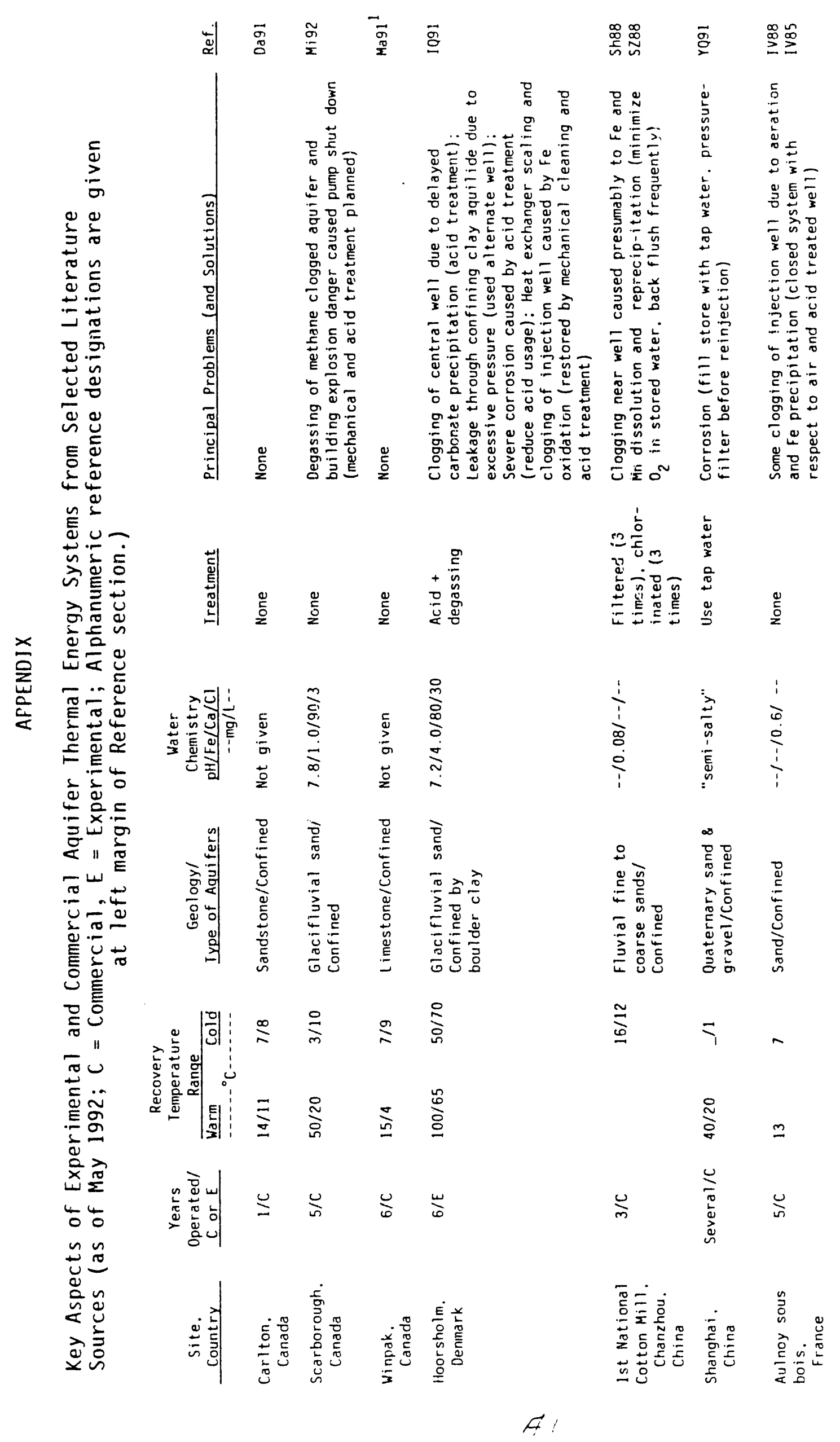




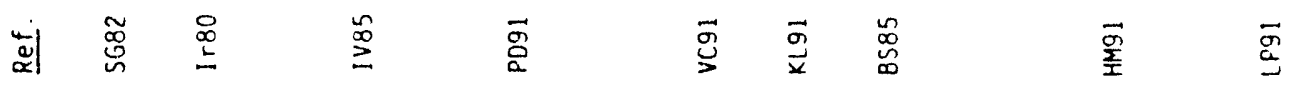

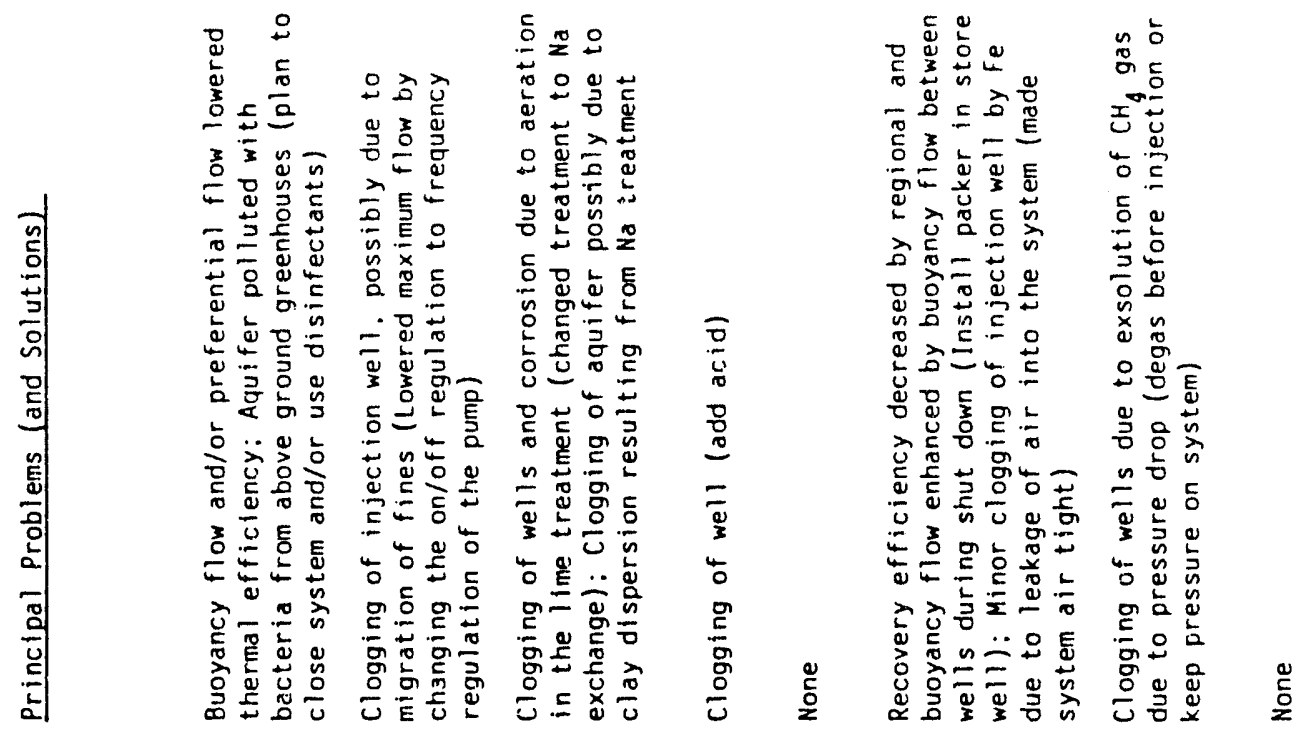

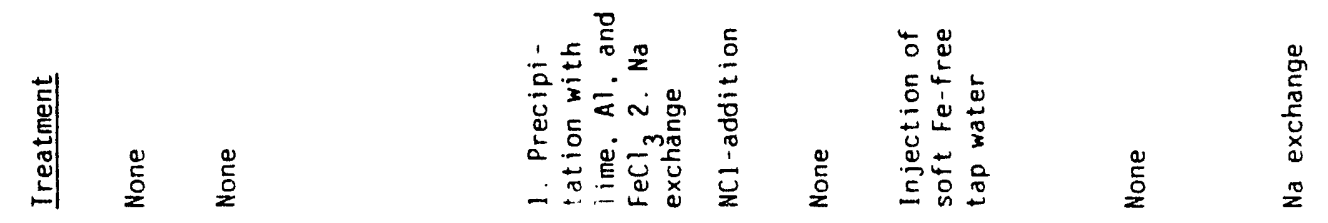

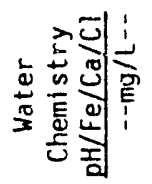

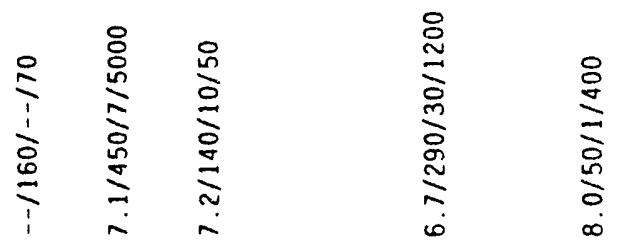

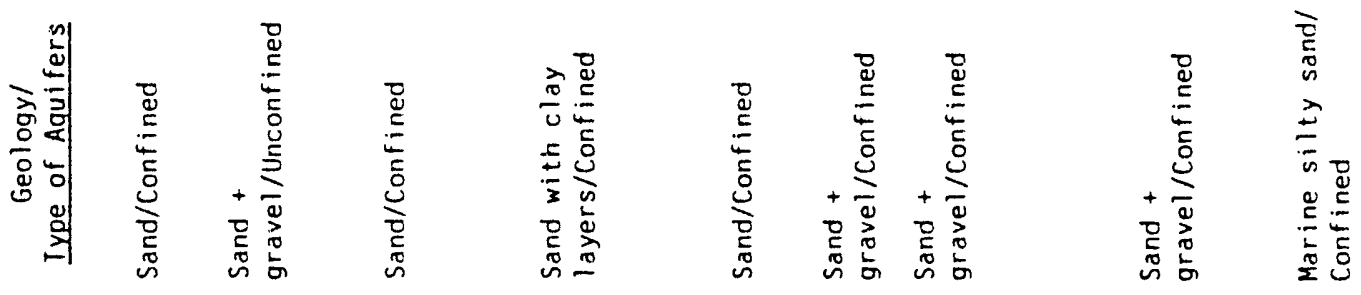

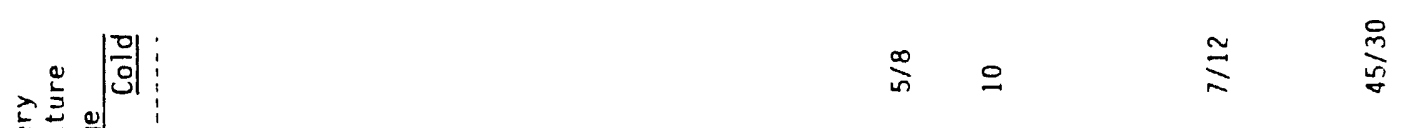

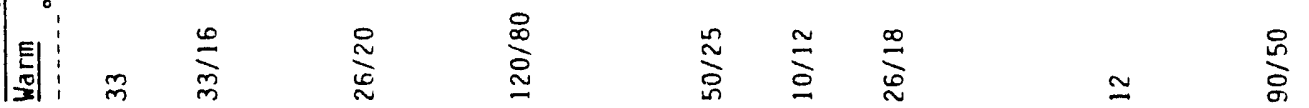

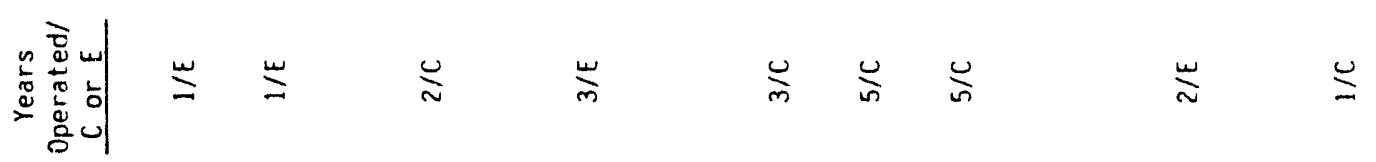

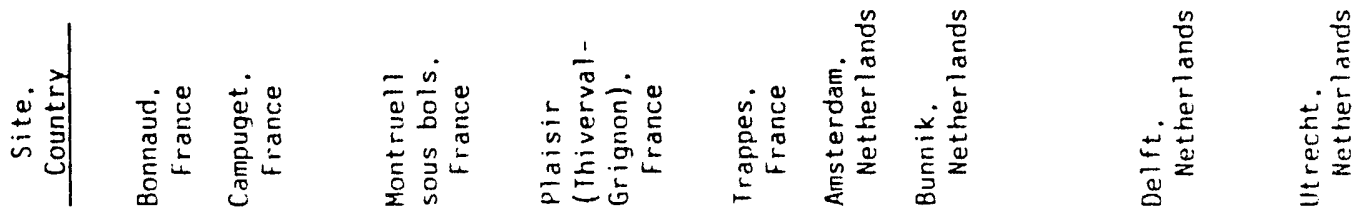




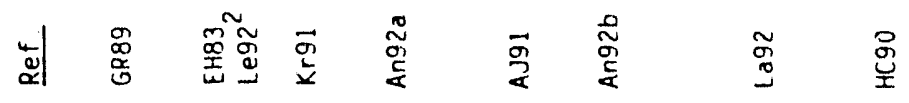

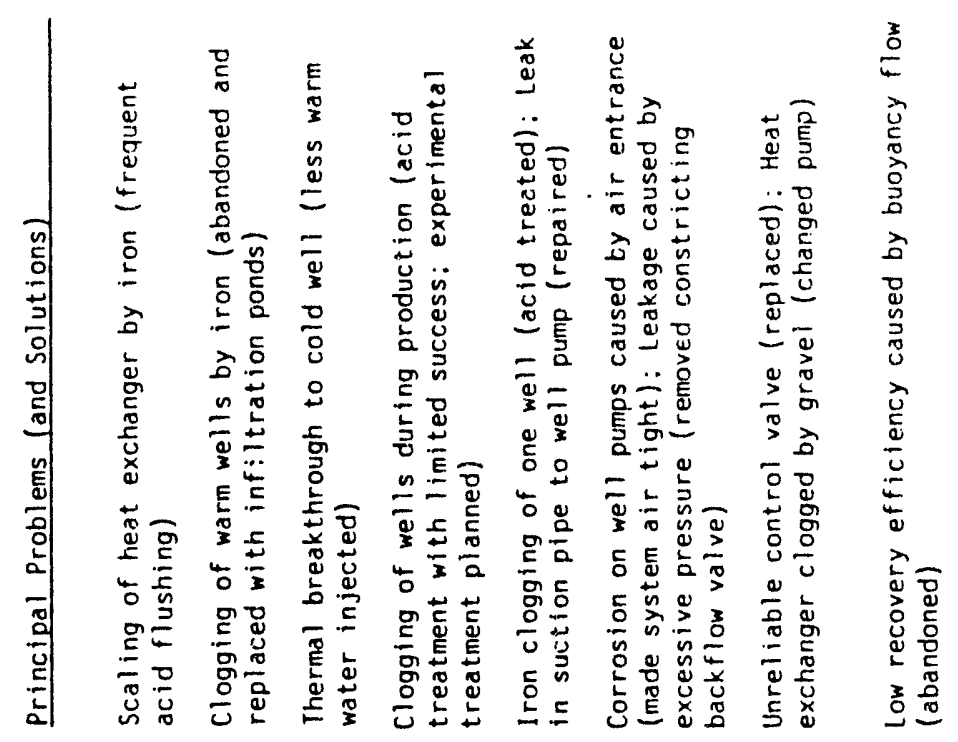

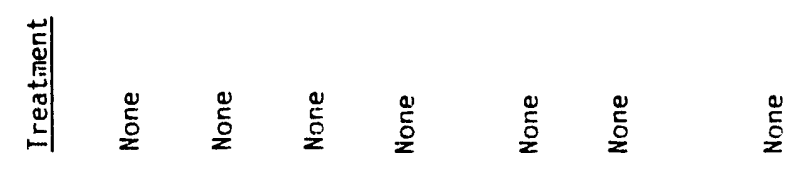

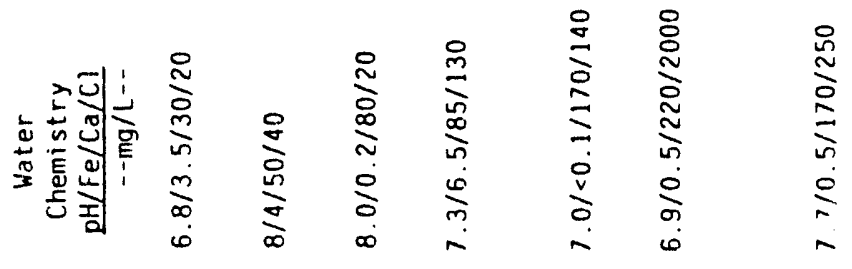

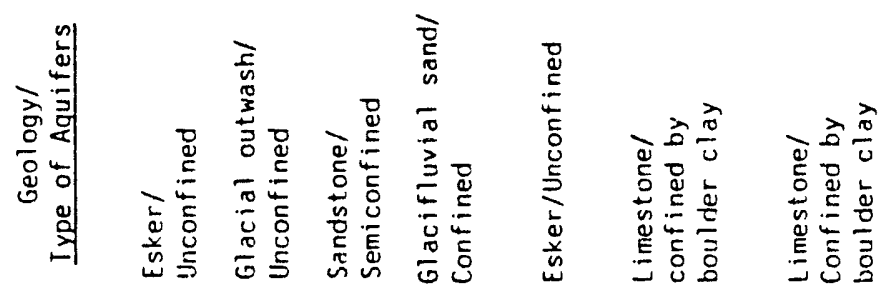

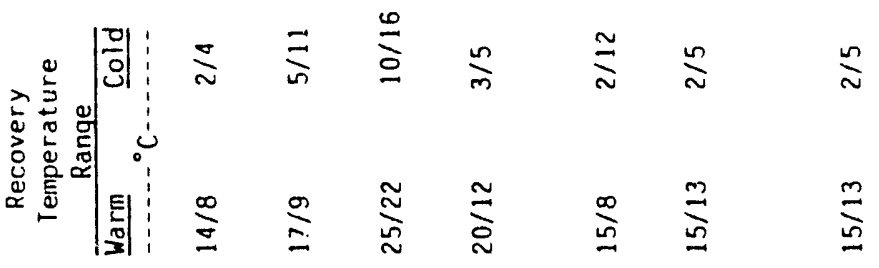

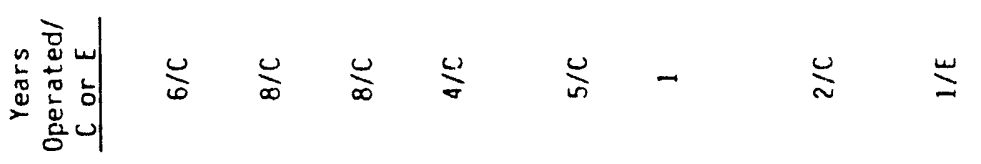

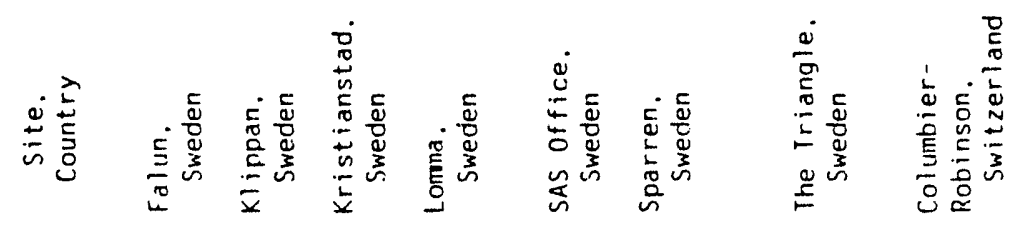




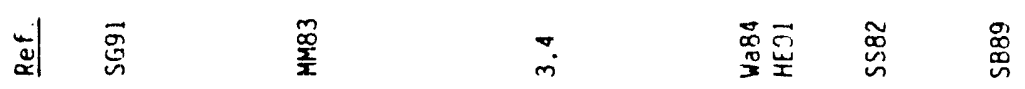

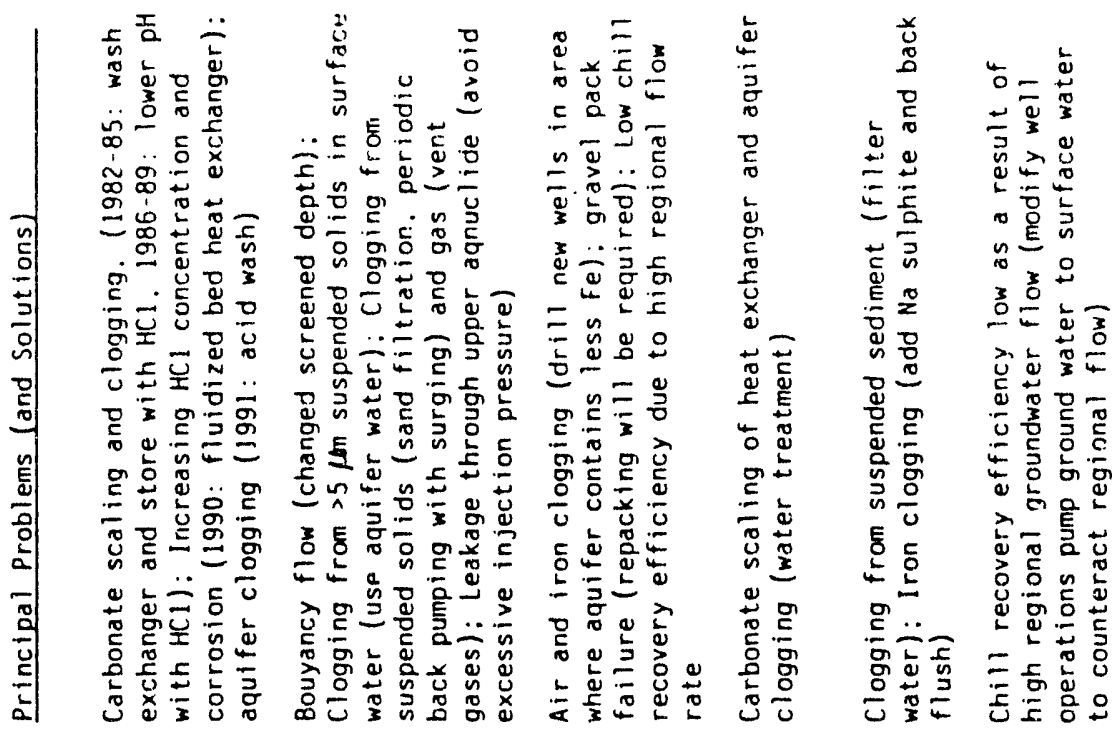

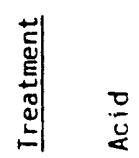

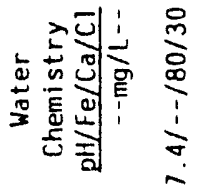

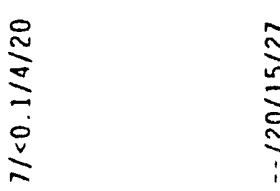

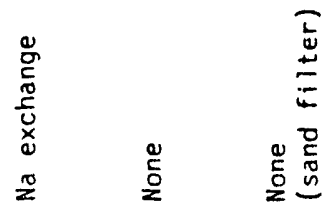

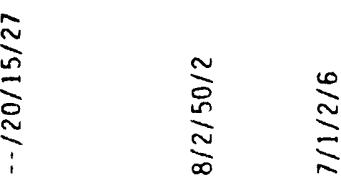

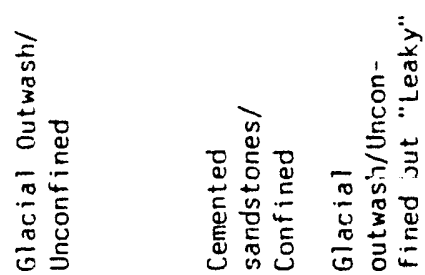

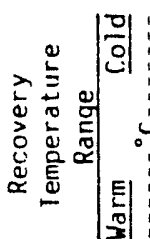

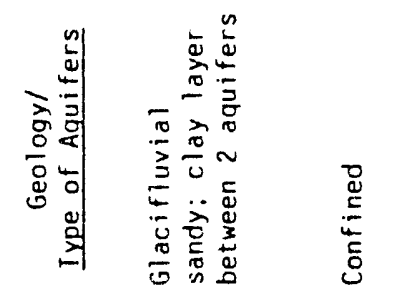

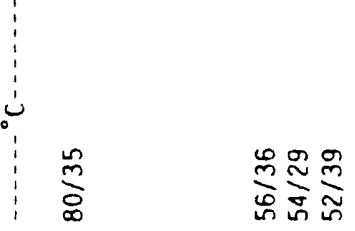

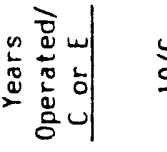

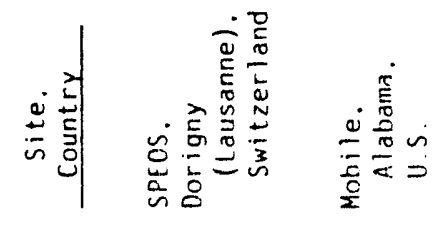

in

$\sim$

$\sim \quad \stackrel{\Xi}{\Xi}$

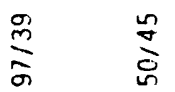



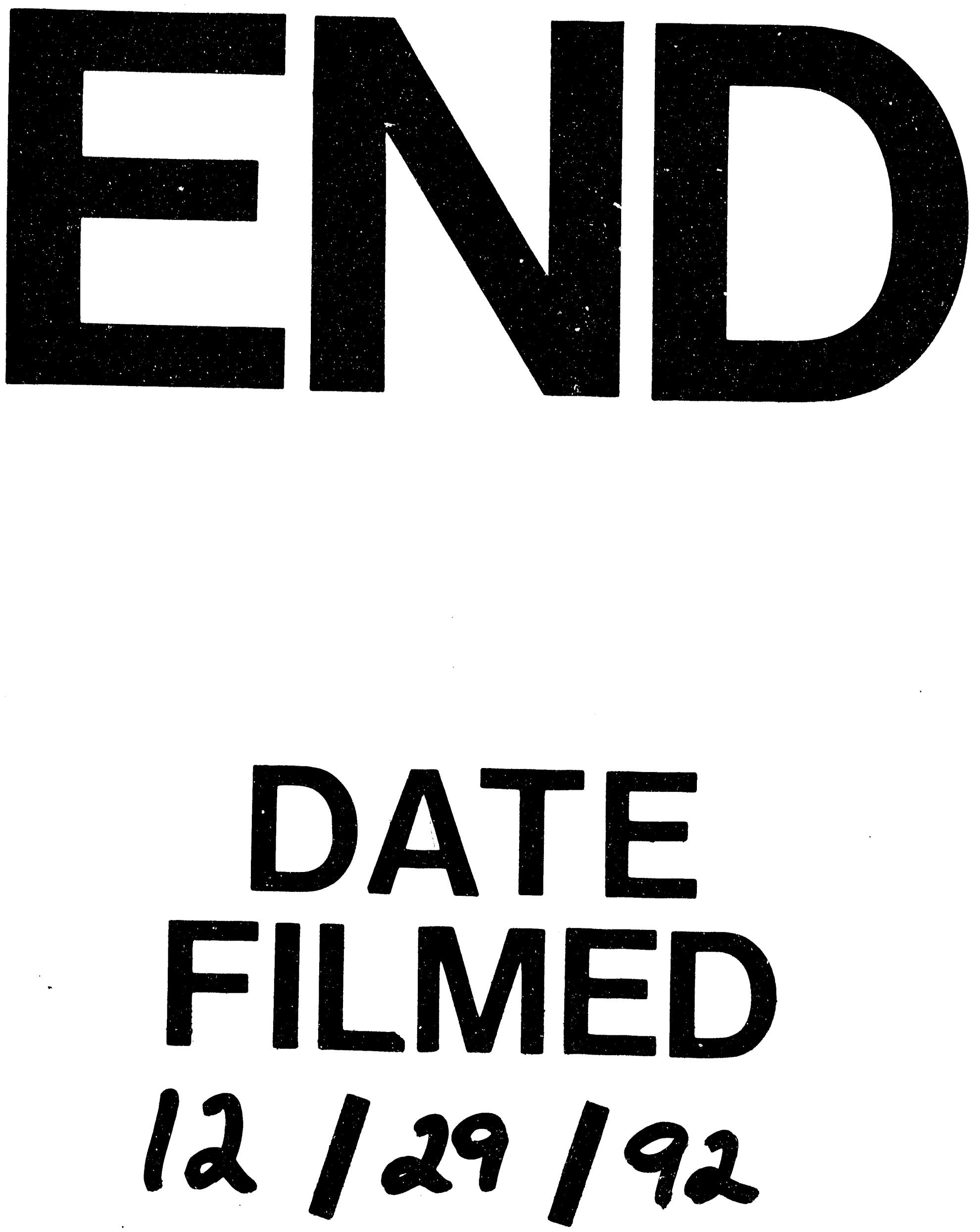